\title{
Pengembangan model permainan polo air sebagai pembelajaran pendidikan jasmani bagi siswa sekolah dasar kelas atas
}

\author{
Wing Prasetya Kurniawan ${ }^{1 *}$, Suharjana ${ }^{2}$ \\ ${ }^{1}$ SMP Institut Indonesia Yogyakarta, Jl. Urip Sumoharjo No.46, Klitren, Gondokusuman, Kota \\ Yogyakarta, 55222. \\ ${ }^{2}$ Fakultas IImu Keolahragaan UNY, Universitas Negeri Yogyakarta. \\ *Corresponding Author. Email: indonesia.institut@yahoo.com,suharjana_fikuny@yahoo.com
}

\begin{abstract}
Abstrak
Penelitian ini bertujuan menghasilkan model permainan polo air sebagai pembelajaran pendidikan jasmani bagi siswa sekolah dasar kelas atas. Model permainan ini diharapkan mampu mengembangkan aspek afektif, kognitif, dan psikomotor bagi siswa sekolah dasar kelas atas. Hasil penelitian berupa model permainan, yang berisikan 10 model permainan, yaitu: (1) permainan satu sapu, (2) permainan lingkaran lumba, (3) permainan jaga kertasnya, (4) permainan estalun, (5) permainan sirip hiu, (6) permainan bom nelayan, (7) permainan lumba berebut bola, (8) permainan lempar target, (9) permainan lempar kejar, dan (10) permainan polo air. Model permainan disusun dalam bentuk buku pedoman dan DVD dengan dengan judul "Permainan Polo Air".
\end{abstract}

Kata kunci: model permainan, polo air, siswa sekolah dasar kelas atas

\section{Developing a water polo game model as a physical educational learning for the upper class of elementary school students}

\begin{abstract}
This study aims to produce a water polo game model as a physical education learning for the upper class of elementary school students wich is decent. The simple game model is expected to be able to develop affective, cognitive and psychomotor domains for the upper class of elementary school students. The result of the research is a simple game model consisting of 10 models of the game, namely: (1) satu sapu, (2) lingkaran lumba, (3) jaga kertasnya, (4) estalun, (5) sirip hiu, (6) bom nelayan, (7) lumba berebut bola, (8) lempar target, (9) lempar kejar, and (10) polo air. Model games are arranged in the form of manuals and DVDs with the title "Water Polo Game".
\end{abstract}

Keyword: model of the game, water polo, elementary school students

\section{PENDAHULUAN}

Mata pelajaran penjasorkes sangat penting diajarkan pada sekolah dasar. Penjasorkes merupakan bagian integral dari pendidikan secara keseluruhan yang memiliki peranan dalam membina pertumbuhan fisik, pengembangan psikis, keterampilan motorik, pengetahuan dan penghayatan nilai-nilai serta pembentukan pola hidup yang sehat. Tujuan penjasorkes di sekolah dasar juga mempertimbangkan adanya tujuan pembelajaran, kemampuan siswa, metode pembelajaran, materi, sarana dan prasarana, serta aktivitas pembelajaran. Materi dalam penjasorkes mempunyai beberapa aspek di antaranya aspek permainan dan olahraga, aspek pengembangan, aspek uji diri/senam, aspek ritmik, aspek akuatik, aspek pendidikan luar kelas, dan aspek kesehatan. Aspek permainan dan olahraga merupakan aspek yang sangat favorit bagi anak. Materi permainan dan olahraga dilakukan secara perseorangan, berpasangan, dan beregu. Permainan mengajarkan nilai-nilai yang terdiri dari nilai kerjasama, sportivitas, kejujuran, toleransi, dan percaya diri. 
Materi akuatik merupakan materi yang tertera dalam standar kompetensi dan kompetensi dasar sekolah dasar kelas atas. Salah satu tingkat pencapaian perkembangan dalam kurikulum sekolah dasar melalui aktivitas akuatik adalah memperagakan gerakan tungkai dalam meluncur, cara bernafas dalam berenang, melakukan gerakan lengan dalam meluncur, dan memperagakan dasar-dasar keselamatan di air. Selain itu juga melalui aktivitas pembelajaran yang dilakukan di air dapat melatih keberanian dan percaya diri. Pelaksanaan pembelajaran akuatik dilakukan di kolam renang. Sekolah dasar yang belum belum memiliki kolam renang pada periode tertentu menyewa kolam renang umum. Hal tersebut mengindikasikan bahwa guru Penjasorkes menyadari kebutuhan mengenalkan siswa pada lingkungan aktivitas akuatik.

Mengingat aktivitas akuatik melalui model permainan di air sangat baik untuk diajarkan di sekolah dasar khususnya kelas atas, maka sebagai pengajar semestinya melaksanakan kegiatantersebut. Pembelajaran akuatik melalui permainan dapat membantu pertumbuhan anak secara optimal seperti penambahan tinggi badan, kekuatan masa otot, dan kecepatan reaksi (Susanto, 2014, p.115). Hasil Penelitian yang dilakukan oleh Nur Sita Utami pada tahun 2012 mendapatkan bahwa model pengenalan air dapat mengembangkan aspek kognitif, afektif, dan psikomotor melalui 6 permainan yaitu: (1) bola warna, (2) air tumpah, (3) harta karun, (4) mandi pagi, (5) hewan laut, dan (6) balap donat dan kacang, sehingga layak digunakan dalam pembelajaran TK kelompok B (Utami \& Sukadiyanto, 2014, p.204).

Memperhatikan keadaan dan kepentingan siswa, maka sebagai pengajar guru harus mengusahakan terjadinya interaksi edukatif, yaitu interaksi antara guru dengan anak didik yang didasarkan atas nilai-nilai dan norma-norma pendidikan yang terarah pada tercapainya tujuan pendidikan. Selain itu juga diperlukan pendekatan-pendekatan pembelajaran yang menarik, menyenangkan dan tidak membosankan. Pembelajaran yang membosankan pada siswa sekolah dasar akan menyebabkan menurunnya motivasi untuk terlibat dalam pembelajaran pendidikan jasmani (Haichun, 2013, p.144).

Hasil observasi dan wawancara yang dilakukan peneliti di sekolah dasar terdapat beberapa permasalahan di lapangan, hal ini dibuktikan dari hasil observasi dan wawancara peneliti ke beberapa sekolah dasar yaitu SD Negeri Minomartani 6, SD Negeri Brengosan 2, dan SD Negeri Dayuharjo, adapun hasilnya yaitu:

Pertama, proses pembelajaran kurang efektif dalam hal kemampuan guru. Hal ini disebabkan oleh kurangnya kreativitas guru dalam memberikan materi akuatik melalui pendekatan bermain. Guru beranggapan bahwa materi akuatik identik dengan gerak dasar berenang. Selama proses pembelajaran akuatik yang berlangsung guru hanya mengajarkan teknik dasar berenang yaitu teknik dasar meluncur (menggerakkan tungkai), mendayung (menggerakkan lengan), dan ambil nafas. Guru belum mengetahui bahwa pembelajaran yang dilakukan di kolam renang tidak selalu belajar teknik, namun dapat berupa model permainan.

Kedua, proses pembelajaran kurang efektif dalam hal penggunaan waktu. Waktu yang tersedia untuk proses pembelajaran tidak digunakan secara optimal, hal ini dibuktikan melalui observasi atau pengamatan langsung di lapangan. Waktu pembelajaran aktivitas akuatik yang tertulis dalam Rencana Pelaksanaan Pembelajaran (RPP) yaitu 140 menit atau 4 jam pelajaran (4x35 menit), waktu yang digunakan pembelajaran di kolam renang yaitu 110 menit, sedangkan 30 menit digunakan untuk persiapan menuju kolam. Akan tetapi waktu 110 menit tidak dimanfaatkan guru dengan baik, dengan materi teknik dasar berenang yang dilakukan secara berulang-ulang menjadikan siswa cepat merasa bosan, saat 2 jam pelajaran (70 menit) telah berlangsung terlihat siswa mulai tidak mengikuti arahan guru, sering main sendiri dan beberapa siswa hanya duduk dipinggir kolam.

Ketiga, pemberian aktivitas akuatik terkendala dalam hal sarana dan prasarana, terutama ketersediaan kolam renang. SD Negeri Minomartani 6, SD Negeri Dayuharjo dan SD Negeri Brengosan 2 tidak memiliki kolam renang, akan tetapi dalam pelaksanaan aktivitas akuatik sekolah tersebut menyewa fasilitas kolam renang di Merapi View dan Tirta Arta. Saat observasi lapangan terlihat kolam renang yang kurang memadai ditinjau dari segi keamaan dan keselamatan siswa sekolah dasar kelas atas dikarenakan ukuran dan kedalaman kolam ini yang bervariasi yaitu satu kolam dengan dua kedalaman antara $75 \mathrm{~cm}$ 
sampai $200 \mathrm{~cm}$. Alat yang digunakan dalam proses pembelajaran akuatik hanya sebatas pelampung dengan jumlah 15 buah. Dengan keterbatasan pelampung yang tidak mencukupi dengan jumlah siswa satu kelas yaitu 22 siswa, terlihat sebagian siswa hanya menunggu giliran dalam hal penggunaan pelampung.

Berdasarkan analisis hasil observasi dan wawancara tentang pelaksanaan pembelajaran akuatik menunjukkan bahwa pembelajaran akuatik sudah mendapatkan perhatian dari guru Penjasorkes. Pemilihan kolam renang yang tepat dan strategis diperlukan demi standar keselamatan siswa. Setelah melakukan observasi beberapa lokasi kolam renang di daerah Ngaglik Kabupaten Sleman, peneliti memilih kolam renang yang strategis yaitu di kolam renang Tirtasari dengan ukuran $10 \times 25$ m dan kedalaman kolam 75 $\mathrm{cm}$.

Secara umum, Mata pelajaran Penjasorkes di sekolah dasar dikemas dalam bentuk permainan dan tidak diarahkan untuk menguasai cabang olahraga dan permainan tertentu, namun lebih mengutamakan proses perkembangan motorik siswa dari waktu ke waktu (Ermawan, 2014, p.112). Oleh karena itu, pembelajaran akuatik di sekolah dasar dilakukan melalui pendekatan bermain yang didalamnya terdapat unsur teknik berenang. Sehingga pembelajaran sesuai dengan kurikulum sekolah dasar kelas atas.

Permainan polo air merupakan salah satu cabang olahraga yang menggabungkan teknik dasar olahraga renang dan basket. Pengembangan permainan polo air berdasarkan konsep bermain yang disesuaikan dengan kurikulum dan karakteristik anak sekolah dasar kelas atas. Permainan polo air pada dasarnya permainan yang mudah dilakukan, untuk itu penyederhanaan baik alat, ukuran lapangan maupun peraturan menjadi hasil modifikasi dari permainan polo air yang sebenarnya. Konsep dasar dari permainan ini adalah lempar tangkap bola dan memasukkan bola ke gawang sehingga harapannya agar anak-anak dapat bermain polo air secara mudah dan sederhana namun tetap mencapai kepuasan, kegembiraan, dan dapat aktif bergerak.

Cara mengenalkan dan mengembangkan permainan polo air melalui pembelajaran di sekolah dasar maka perlu membuat pengembangan dengan memodifikasi permainan sesuai dengan tingkat pertumbuhan dan perkembangan anak sekolah dasar. Untuk memahami permainan polo air di sekolah dasar, maka yang diajarkan guru penjasorkes kepada siswa adalah konsep bermain polo air.

Pengembangan model permainan polo air dengan cara modifikasi permainan dimaksudkan agar anak lebih siap secara fisik dan psikis dalam menerima permainan. Pengembangan harus memerhatikan kesempatan dan layanan yang sama bagi setiap siswa dalam permainan tersebut. Pengembangan permainan polo air juga harus memerhatikan keterampilan dasar dominan yang dipandang dapat mendukung pencapaian keberhasilan dalam memainkan teknik-teknik dasar polo air. dominan dalam bermain antara lain melempar, menangkap, menyelam, dan meluncur.

Modifikasi permainan berupa perubahan ukuran, bentuk, dan bahan dari alat yang digunakan, dan perubahan ukuran lapangan, serta peraturan permainan yang lebih jelas dan sederhana. Esensi dari modifikasi permainan polo air adalah untuk memudahkan anak menguasai teknik dasar dan memperoleh pengalaman sukses tanpa ada rasa bosan, jenuh, dan keluhan lelah saat melakukan permainan. Modifikasi permainan diharapkan dapat memberi kesempatan yang sama bagi semua siswa, sehingga permainan tidak hanya dimonopoli oleh anak yang lebih mampu. Berdasarkan uraian tersebut, diperlukan pengembangan model permainan polo air sebagai pembelajaran pendidikan jasmani bagi siswa sekolah dasar kelas atas.

\section{METODE PENELITIAN}

\section{Jenis Penelitian}

Penelitian ini merupakan penelitian pengembangan (research and development) untuk menghasilkan produk pendidikan. Dunia pendidikan membutuhkan metode penelitian dan pengembangan untuk meningkatkan kualitas pendidikan. Penelitian dan pengembangan merupakan proses untuk mengembangkan dan memvalidasi produk pendidikan berupa barang, prosedur, maupun metode pembelajaran. Berdasarkan penjelasan Gall, Gall, \& Borg 
(2003, p.569) bahwa penelitian dan pengembangan menggunakan temuan penelitian untuk merancang prosedur dan produk baru, kemudian secara sistematis diuji di lapangan, dievaluasi, dan disempurnakan sampai memenuhi kriteria tertentu dari unsure efektiitas, kualitas, atau standar yang sama. Penelitian pendahuluan dilakukan untuk menganalisis pelaksanaan pembelajaran akuatik bagi siswa sekolah dasar kelas ats sehingga dihasilkan data analisis kebutuhan. Berdasarkan data analisis kebutuhan dilakukan pemilihan variabel yang berpotensi dapat dikembangkan. Pengembangan dilakukan untuk mengahsilkan produk berupa model permainan polo air bagi siswa sekolah dasar kelas atas yang disusun dalam buku pedoman dan $C D$ (compact disc). Pengembangan isi dan tujuan model berpedoman pada kurikulum sekolah dasar kelas atas yang termuat dalam standar kompetensi dan kompetensi dasar kelas atas materi akuatik. Hal tersebut memudahkan guru dalam mengimplementasikan model ke dalam rencana kegiatan harian. Fokus pengembangan model berdasarkan aspek kognitif, afektif, dan psikomotor. Pengembangan pada tahap pemilihan bentuk aktivitas akuatik disesuaikan dengan tahap-tahap perkembangan serta karakteristik siswa sekolah dasar kelas atas.

\section{Waktu dan Tempat Penelitian}

Penelitian pengembangan ini mengambil tempat di SD Negeri Minomartani 6, SD Negeri Brengosan 2, dan SD Negeri Dayuharjo Ngaglik Sleman. Waktu penelitian dilaksanakan pada jam pelajaran pendidikan jasmani olahraga dan kesehatan sekolah dasar kelas atas khususnya kelas V (lima).

\section{Subjek Penelitian}

Subjek coba dalam penelitian ini adalah siswa sekolah dasar kelas atas khususnya kelas $\mathrm{V}$ (lima). Tempat penelitian dibatasi pada sekolah dasar yang berada di Kecamatan Ngaglik, Kabupaten Sleman. Uji coba produk skala kecil melibatkan siswa kelas V (lima) sebanyak 20 siswa dari Sekolah Dasar Negeri Minomartani 6, sedangkan uji coba produk skala besar melibatkan siswa kelas $\mathrm{V}$ (lima) sebanyak 22 siswa dari Sekolah Dasar Negeri Brengosan 2 dan siswa kelas V (lima) sebanyak 22 siswa dari Sekolah Dasar Negeri Dayuharjo.

\section{Prosedur Pengembangan}

Pelaksanaan prosedur pengambangan dan penelitian dalam penelitian ini mengadaptasikan langkah-langkah penelitian dan pengembangan pendidikan yang dikembangkan oleh Gall, Gall, \& Borg. Langkah-langkah penelitian dan pengembangan menurut (Borg, Borg, \& Gall, 2003, p.570) yang harus ditempuh sebagai berikut: (1) studi pendahuluan dan pengumpulan data (kajian pustaka, pengamatan lapangan, membuat kerangka kerja penelitian), (2) perencanaan (tujuan penelitian, dana, waktu, prosedur penelitian, berbagai bentuk partisipasi), (3) mengembangkan produk awal (merencanakan draft awal produk), (4) uji coba awal (mencoba draft produk ke wilayah dan subyek yang terbatas), (5) revisi untuk penyusunan produk utama, (6) uji coba lapangan utama (uji coba ke wilayah dan subyek yang lebih luas), (7) revisi untuk menyusun produk operasional, (8) uji coba produk operasional (uji efektif produk), (9) revisi produk final (revisi produk yang efektif), dan (10) desiminasi dan implementasi produk hasil pengembangan.

Langkah penelitian dan pengembangan ini dapat dilakukan penyederhanaan sesuai dengan kondisi dan kendala dalam penelitian yang dihadapi (Dwiyoga, 2004, p.6). Adapun langkah-langkah yang ditempuh dalam penelitian dan pengembangan ini adalah sebagai berikut:

\section{Pengumpulan Informasi di Lapangan}

Pengumpulan informasi adalah langkah awal yang dilakukan dalam penelitian ini. Dalam kajian awal yang dilakukan adalah kajian tentang isi dari muatan kurikulum pendidikan jasmani di sekolah dasar. Fokus dari kajian adalah penyelarasan antara muatan 
isi dari kurikulum dan materi yang di berikan oleh guru yang tertuang di rencana pelaksanan pembelajaran (RPP). Studi yang dilakukan melalui observasi dan wawancara langsung ke sekolah melalui guru pendidikan jasmani sekolah dasar. Adapun fokus dari observasi dan wancara adalah pada pembelajaran akuatik di sekolah dasar kelas atas. Observasi dan wawancara dilakukan di tiga sekolah dasar yaitu: Sekolah Dasar Negeri Minomartani 6, Sekolah Dasar Negeri Brengosan 2, dan Sekolah Dasar Negeri Dayuharjo. Dari hasil observasi di lapangan dan didukung hasil wawancara dapat diterjemahkan bahwa adanya potensi masalah antara lain: (1) pembelajaran akuatik di sekolah dasar kelas atas masih kurang berkembang karena guru Penjasorkes kesulitan dalam memodifikasi pembelajaran melalui pendekatan bermain, (2) guru kesulitan mengembangkan kegiatan pembelajaran akuatik melalui pendekatan bermain dan memodifikasi permainan polo air, (3) waktu dalam proses pembelajaran pembelajaran tidak berjalan dengan efektif, (4) pemilihan kolam renang belum memenuhi standar keamanan dan keselamatan yaitu ukuran dan kedalaman kolam yang bervariasi yaitu satu kolam dengan dua kedalaman antara $75 \mathrm{~cm}$ sampai $200 \mathrm{~cm}$, dan (5) Guru kesulitan dalam memodifikasi alat yang digunakan dalam pembelajaran akuatik di sekolah dasar kelas atas.

Melakukan analisis terhadap informasi yang telah dikumpulkan

Segala informasi yang sudah didapat dari informasi lapangan selanjutnya di analisis. Analisis dilakukan pertama adalah studi pustaka dan yang kedua studi hasil observasi. Studi pustaka adalah pengumpulan teori- teori yang ada dengan penerapan permasalahan yang ada dilapangan. Selain itu analisis studi pustaka digunakan untuk pemantapan dalam memfokuskan masalah yang dikaji. Sementara analisis dari hasil observasi dan wawancara dilakukan untuk mengetahui kebenaran asumsi peneliti dari kondisi nyata di lapangan mengenai permasalahan yang ada. Dalam analisis wawancara akan dijadikan rujukan penguat asumsi dari kondisi nyata dilapangan sesuai dengan permasalahan yang ada. Dalam pengumpulan informasi lapangan juga di lengkapi dengan studi dokumentasi tentang kondisi kolam yang dilakukan praktek pembelajaran akuatik serta model pembelajaran akuatik yang diberikan oleh guru penjasorkes. Hasil analisis dokumentasi dapat digunakan dalam referensi pembuatan model permainan yang akan di ujicobakan dalam pembelajaran pendidikan jasmani.

Hasil analisis dari observasi dan wawancara dihitung dan di simpulkan adanya analisis kebutuhan yang di perlukan oleh guru pendididkan jasmani. Selanjutnya hasil dari analisis disimpulkan mengenai permasalahan- permasalahan yang dihadapi guru sekolah dasar kelas atas dalam pembelajaran pendidikan jasmani khususnya aktivitas akuatik. Dari hasil analisis inilah dapat disimpulkan berdasar analisis kebutuhan dan hal solusi yang dapat di buat pada penelitian ini.

\section{Pengembangan Produk Awal (Draf Model)}

Setelah proses analisis, dalam penelitian ini dimulai mengembangkan suatu produk guna membantu guru sekolah dasar mengatasi permasalahan yang ditemui dalam proses pembelajaran produk pengembangan masih berupa produk awal. Produk yang akan dibuat juga berdasar pada kebutuhan yang dibutuhkan dalam proses pembelajaran pendidikan jasmani di sekolah dasar.

Dalam penelitian pengembangan ini memformulasikan suatu produk yang berguna membantu guru sekolah dasar kelas atas untuk mengatasi permasalahan yang ditemui dalam pelaksanaan pembelajaran aktivitas akuatik serta pengenalan olahraga permainan polo air pada siswa. Produk yang akan dibuat masih dalam produk awal dan dalam pengembangan produk (draft awal) berdasar pada: (a) analisis tujuan pembelajaran di sekolah dasar dan karakter produk, (b) analisis karakter siswa, (c) menetapkan tujuan dan bentuk permainan, (d) menetapkan strategi pengorganisasian dalam pembelajaran, (e) menganalisa kenyamanan produk saat digunakan, yang meliputi keamanan dan kenyamanan, dan (f) mempertimbangkan akan hasil dari permainan akan meningkatkan kebugaran jasmani siswa.

\section{Validasi Ahli dan Revisi}


Sebelum dilakukan uji coba skala kecil terhadap produk awal, maka produk harus mendapat validasi oleh para ahli. Dalam hal ini validasi dilakukan oleh para ahli (expert) yaitu: (1) ahli pendidikan jasmani sekolah dasar (2) ahli permainan, serta (3) praktisi (guru) pendidikan jasmani sekolah dasar. Tujuan validasi produk adalah untuk mendapatkan pengesahan bahwa produk yang di buat sesuai dan layak digunakan, serta untuk mendapatkan masukan terhadap draf produk awal yang dikembangkan. Tujuan lain dari validasi draf awal adalah untuk mengantisipasi kesalahan pada para pengguna produk. Proses validasi para ahli menilai dan memberi masukan terhadap produk awal. Berdasarkan hal tersebut dilakukan revisi terhadap produk awal. Proses revisi tersebut terus dilakukan sampai produk awal mencapai batas nilai tertentu yang ditetapkan, yang menunjukan bahwa produk awal tersebut valid dan layak diujicobakan. Sedangkan revisi dilakukan untuk perbaikan produk awal. Proses revisi terus dilakukan sampai produk awal mencapai batasan nilai yang ditentukan, selajutnya jika produk awal sudah ditetapkan maka produk tersebut sudah menunjukkan produk awal yang valid dan layak diujicobakan.

\section{Uji Coba Lapangan Skala Kecil dan Revisi}

Uji coba skala kecil dilakukan untuk mengetahui tingkat implementasi model permainan yang dikembangkan. Uji coba skala kecil ini dilakukan dengan mengimplementasikan model permainan yang telah dibuat. Uji coba skala kecil dilaksanakan pada satu sekolah yang telah ditentukan. Uji coba lapangan skala kecil dilakukan di subyek coba. Subyek coba adalah siswa kelas V (satu) Sekolah Dasar Negeri Minomartani 6. Dalam uji coba produk di lapangan didokumentasikan dalam bentuk Compact Disc (CD), yang kemudian diobservasi oleh para ahli materi. Hasil observasi dari ahli materi digunakan sebagai revisi produk selanjutnya untuk di perbaiki dan selanjutnya diteruskan pada uji skala besar.

\section{Uji Coba Lapangan Skala Besar dan Revisi}

Pada skala besar yang melibatkan lebih banyak siswa dan guru yang dilibatkan. Uji coba skala besar sudah tidak melibatkan siswa yang di libatkan dalam uji coba skala kecil. Pada penelitian ini melibatkan siswa dua sekolah yang berbeda. Alur dari penelitian yang dilaksanakan juga relatif sama dengan skala kecil akan tetapi pada skala besar lebih mengutamakan keamanan dan keefektifan model permainan serta waktu yang dilakukan dalam pembelajaran pada jam pelajaran. Proses revisi produk dilakukan setelah mendapat masukan dari para ahli materi untuk menghasilkan produk final. Proses revisi beradasar pada masukan para ahli dan praktisi. Masukan dari praktisi juga menjadi masukan dalam revisi produk.

\section{Pembuatan Produk Akhir}

Hasil dari penelitian yang dibuat ini nantinya dapat digunakan oleh praktisi pendidikan jasmani. Dari produk yang sudah melewati poses tahap demi tahap, jika sudah melewati validasi produk dan melalui revisi selanjutnya dibuat produk final. Dalam hal ini pembuatan produk final dalam penelitian pengembangan ini berupa buku panduan model permainan bola kecil yaitu model "Permainan Polo Air". Didalamnya terdapat sepuluh permainan yang di susun dalam buku modul panduan. Isi dari buku panduan meliputi tata cara pelaksanaan model, peralatan yang digunakan, peraturan pelaksanaan permainan beserta panduan keselamatan. Didalam buku panduan selain gambar dan aturan permainan juga disertakan draf penilaian dari semua tahap kegiatan, sehingga harapanya dengan menggunakan model "Permainan Polo Air" diharapkan sudah satu paket komplit dalam mengisi pertemuan dalam materi permainan bola kecil di sekolah dasar kelas atas. Dari segi visualnya dibuat dalam video yang bisa di putar dengan aplikasi komputer atau laptop, model tersebut digunakan dalam pembelajaran Penjasorkes pada sekolah dasar kelas atas.

\section{Data, Instrumen,dan Teknik Pengumpulan Data}

Jenis data yang diperoleh dalam penelitian pengembangan ini berupa data kualitatif dan data kuantitatif. Data kualitatif berasal dari: (1) data masukan dari para ahli materi dan guru pelaku uji coba, dan (2) hasil wawancar dengan guru penjas SD. Data kuantitatif diperoleh dari: (1) penilaian ahli materi terhadap penyusunan draf model awal permainan, (2) 
penilaian ahli materi terhadap keefektifan model permainan dalam skala kecil dan skala besar dan (3) penilaian ahli materi terhadap guru pelaku uji coba, serta (4) uji efektifitas model yang di terapkan dari model permainan yang dibuat.

Instrumen yang digunakan untuk pengumpulan data dalam penelitian dan pengembangan ini terdiri dari: (1) pedoman observasi lapangan, (2) pedoman wawancara, (3) angket skala nilai, (4) tes penilaian hasil belajar, dan (5) kuisioner untuk siswa.

Teknik pengumpulan data pertama adalah studi pendahuluan dilakukan dengan observasi di lapangan, wawancara serta studi dokumentasi. Studi pendahuluan untuk mengetahui aspek permasalahan dan kebutuhan yang ada di lapangan. Selanjutnya dari permasalahan dapat diidentifikasi dan ditelusuri akan kebutuhan yang diperlukan dalam proses pembelajaran pendidikan jasmani di Sekolah Dasar.

Teknik pengumpulan data kedua menggunakan angket skala nilai. Skala nilai ini digunakan untuk menilai kelayakan model permainan. Skala nilai adalah sebuah instrumen yag mewajibkan pengamat untuk menetapkan subjek pada kategori dengan memberikan penilaian pada kategori-kategori tersebut. Skala nilai yang digunakan dalam penelitian dan pengembangan menggunakan skala guttman. Sugiyono (2015, p.169) menyatakan skala pengukuran dengan tipe ini, akan didapat jawaban yang tegas yaitu "ya-tidak", "benar-salah", "pernah-tidak pernah", "positif-negatif" dan lain-lain. Data yang diperoleh dapat berupa data interval atau rasio dikhotomi (dua alternatif). Mustafa (2009, p.74) menyatakan pada skala dikotomi, alternatif jawaban yang disediakan pada dasarnya menggunakan logika "benar (true)" dan "salah (false)" atau "ya (yes)" dan "tidak (no)". Penelitian menggunakan skala guttman. Cara penggunaan skala nilai yaitu, bilamana muncul gejala atau unsur-unsur seperti yang terdapat dalam klasifikasi data, para pakar dan guru memberikan tanda cek $(\sqrt{ })$ pada kolom kategori yang "Ya". Apabila gejala atau unsur-unsur seperti yang terdapat dalam klasifikasi data dinyatakan sesuai maka nilainya satu (1), apabila dinyatakan "Tidak" maka nilainya nol (0).

Teknik pengumpulan data ketiga menggunakan teknik observasi siswa melalui rubrik penilaian hasil belajar siswa dan kuisioner terhadap respon siswa. Rubrik penilaian siswa dan kuisioner untuk mengetahui motivasi siswa dalam menjalankan proses permainan.

\section{Teknik Analisis Data}

Teknik analisis data yang dilakukan dalam penelitian ini yaitu analisis deskriptif kuantitatif dan analisis deskriptif kualititatif. Analisis deskriptif kuantitatif pengelolaan data dalam penelitian ini menggunakan analisis statistik deskriptif kuantitatif. Teknik analisi data deskriptif kuantitatitf dilakukan pada: (1) hasil penilaian validasi dengan skala nilai ahli materi terhadap draf model permainan sebelum uji coba, (2) data penilaian hasil observasi para observer terhadap model permainan, (3) data hasil observasi observer terhadap keefektifan model permainan polo air dalam proses pembelajaran, dan (4) data hasil penilaian aspek kognitif, afektif, dan psikomotor siswa.

Model yang disusun dianggap layak untuk diujicobakan dengan skala kecil maupun besar apabila secara kuantitatif dihitung skor mencapai standar minimal kelayakan. Norma kategorisasi yang akan digunakan sesuai ketentuan Azwar (2004, p. 109) sebagai berikut:

Tabel 1. Norma kategorisasi yang akan digunakan

\begin{tabular}{ll}
\hline Formula & Kategori \\
\hline$X<(\mu-1,0 \sigma)$ & Kurang/Kurang Efektif \\
$(\mu-1,0 \sigma) \leq X<(\mu+1,0 \sigma)$ & Cukup/Cukup Efektif \\
$(\mu+1,0 \sigma) \leq X$ & Baik/Efektif \\
\hline
\end{tabular}

Dalam penelitian ini norma kategorisasi rendah diasumsikan sebagai kurang/kurang efektif, cukup/cukup efektif, dan baik/efektif. 
Teknik analisis data kualitatif dalam penelitian ini menggunakan hasil observasi, wawancara dan catatan lapangan direduksi, disajikan untuk diberi makna, dan terakhir disimpulkan untuk memperjelas masalah yang ada. Hal tersebut dilakukan untuk memperkuat latar belakang masalah penelitian. Pada proses pengembangan produk, data berupa saran perbaikan dari pendapat observer direduksi, disajikan, kemudian dianalisis untuk diambil kesimpulan sebagai bahan revisi.

\section{HASIL PENELITIAN DAN PEMBAHASAN}

Proses revisi model permainan polo air sebagai pembelajaran pendidikan jasmani bagi siswa sekolah dasar kelas atas telah mengalami 4 kali revisi, yaitu: (1) sebelum validasi, (2) sebelum uji coba produk dengan skala kecil, (3) setelah uji coba skala kecil, dan (4) setelah uji coba dengan skala besar. Tahap revisi keempat merupakan hasil produk akhir model permainan polo air sebagai pembelajaran pendidikan jasmani bagi siswa sekolah dasar kelas atas yang disusun dalam buku pedoman "permainan polo air" terdiri atas sepuluh permainan dilengkapi dengan rencana kegiatan harian dan rubrik penilaian siswa. Alokasi waktu pelaksanaan model pembelajaran akuatik melalui permainan polo air adalah 10 menit pemanasan, 90 latihan inti, dan 10 menit pendinginan. Kesepuluh model permainan disusun berdasarkan keterampilan bergerak di air, teknik dasar berenang dan teknik dasar permainan polo air yang akan dikenalkan dalam model sebagai berikut:

1. Permainan Satu Sapu

Mengenalkan keterampilan bergerak di air dengan rangasangan gerak berjalan dan berlari di air.

2. Permainan Jaga Kertasnya

Mengenalkan keterampilan menolong korban tenggelam dengan rangsangan membawa kertas dan berjalan mundur.

3. Permainan Lingkaran Lumba-lumba

Mengenalkan keterampilan kontrol nafas, memasukkan wajah ke dalam air.

4. Permainan Estalun

Mengenalkan cara meluncur dengan memegang bola.

5. Permainan Sirip Hiu

Mengenalkan cara mendayung tangan dan meluncur dalam teknik dasar renang gaya crawl dengan membawa bola.

6. Permainan Bom Nelayan

Mengenalkan cara passing bola dalam teknik dasar permainan polo air.

7. Permainan Lumba Berebut Bola

Mengenalkan cara passing bola dalam teknik dasar permainan polo air.

8. Permainan Lempar Target

Mengenalkan cara shooting dalam teknik dasar permainan polo air.

9. Permainan Lempar Kejar

Mengenalkan cara shooting dalam teknik dasar permainan polo air dan berlari di air.

10. Permainan Polo Air Mini

Mengenalkan cara bermain polo air yang telah dimodifikasi yaitu tentang aturan bermain polo air, jumlah pemain, ukuran gawang, ukuran bola dan luas lapangan.

Berikut merupakan penjelasan kesesuaian setiap model permainan polo air sebagai pembelajaran pendidikan jasmani bagi siswa sekolah dasar kelas atas. 


\section{Permainan Satu sapu}

Permainan satu sapu merupakan permainan pengenalan di air. Permainan satu sapu dilakukan dengan cara berlari di dalam kolam renang. Permainan ini dilakukan membentuk dua kelompok berseberangan dengan jumlah yang sama. Untuk membedakan antar kelompok maka setiap kelompok dinamakan satu dan sapu. Permainan dilakukan dengan cara ketika nama salah satu kolompok disebut maka, tugasnya yaitu berlari lurus mengejar kelompok lawan.

Aspek kognitif yang akan dicapai dalam permainan ini adalah mengenalkan siswa tentang keterampilan bergerak di air seperti berlari di air.

Aspek Afektif yang akan dicapai dalam permainan ini adalah menumbuhkan rasa percaya diri dan bekerjasama antar siswa.

Aspek psikomotor yang akan dicapai adalah mengembangkan keterampilan berlari di air.

\section{Permainan Jaga Kertasnya}

Permainan jaga kertasnya merupakan pengenalan untuk renang menolong korban tenggelam. Permainan jaga kertasnya dilakukan dengan cara membawa kertas dengan berjalan mundur dan menjaga kertas tidak jatuh di air. Permainan ini dilakukan dengan membentuk kelompok. Setiap kelompok terdiri dari empat siswa. Setiap siswa membawa satu huruf yang disusun berurutan sehingga dalam satu kelompok akan mendapatkan tulisan "POLO". Kertas di bawa di atas kepala dan diusahakan tidak jatuh di air. Siswa yang membawa huruf pertama diberikan ke siswa belakangnya dengan cara berjalan mundur. Cara ini dilakukan sampai siswa yang mendapatkan huruf terakhir dan menyambung kata "POLO" dan menaruhnya di tempat yang tersedia di pinggir kolam.

Aspek kognitif yang akan dicapai dalam permainan ini adalah mengenalkan siswa tentang bentuk keselamatan atau renang menolong.

Aspek Afektif yang akan dicapai dalam permainan ini adalah menumbuhkan rasa percaya diri dan bekerjasama antar siswa.

Aspek psikomotor yang akan dicapai adalah mengembangkan keterampilan berjalan mundur di air.

\section{Permainan Lingkaran Lumba}

Permainan lumba-lumba dilakukan dengan cara menyelam di simpai yang telah tersedia. Setiap kelompok terdiri 5 siswa. Masing-masing siswa mendapatkan bagian hitungan "satu-dua, satu-dua" dan seterusnya sampai siswa terakhir. Ketika ada aba-aba hitungan "satu" maka siswa yang berada pada hitungan "satu" berebut untuk masuk ke simpai dengan cara menyelam. Begitupun sebaliknya ketika mendengar aba-aba hitungan "dua".

Aspek kognitif yang akan dicapai dalam permainan ini adalah mengenalkan siswa tentang tentang teknik dasar berenang fokusnya adalah kontrol nafas.

Aspek Afektif yang akan dicapai dalam permainan ini adalah menumbuhkan rasa percaya diri dan bekerjasama antar siswa.

Aspek psikomotor yang akan dicapai meliputi memasukkan wajah ke dalam air, dan kontrol nafas.

\section{Permainan Estalun}

Permainan estalun dilakukan dengan cara memegang bola dengan posisi tungkai meluncur. Permainan ini dilakukan dengan cara estafet. Masing-masing kelompok terdiri dari 5-6 siswa. Jarak antar siswa adalah 4 meter. Siswa dengan posisi paling belakang membawa bola dengan cara meluncur dan diberikan ke siswa yang berada di depannya. Cara estafet ini dilakukan sampai siswa yang berada di posisi paling depan berhasil memasukkan bola di keranjang yang berada di pinggir kolam.

Aspek kognitif yang akan dicapai dalam permainan ini adalah mengenalkan siswa tentang tentang teknik dasar berenang fokusnya yaitu cara meluncur dan menggerakkan kedua kaki. 
Aspek Afektif yang akan dicapai dalam permainan ini adalah menumbuhkan rasa percaya diri dan bekerjasama antar siswa.

Aspek psikomotor yang akan dicapai meliputi gerak dasar meluncur fokusnya cara menggerakkan kedua kaki dalam renang gaya crawl.

\section{Permainan Sirip Hiu}

Permainan sirip hiu dilakukan dengan cara tangan memegang bola dan mengajarkan anak untuk belajar kayuhan lengan. Permainan ini dilakukan dengan cara estafet. Masingmasing kelompok terdiri dari 5-6 siswa. Jarak antar siswa 4 meter. Siswa dengan posisi paling belakang membawa bola dengan satu tangan. Tangan yang satunya berusaha untuk memberi dayungan saat meluncur. Cara estafet ini dilakukan sampai siswa yang berada di posisi paling depan berhasil memasukkan bola di keranjang yang berada di pinggir kolam.

Aspek kognitif yang akan dicapai dalam permainan ini adalah mengenalkan siswa tentang tentang teknik dasar berenang fokusnya yaitu cara mendayung lengan dan meluncur menggerakkan kedua kaki dalam renang gaya crawl.

Aspek Afektif yang akan dicapai dalam permainan ini adalah menumbuhkan rasa percaya diri dan bekerjasama antar siswa.

Aspek psikomotor yang akan dicapai meliputi gerak dasar meluncur fokusnya cara mendayung legan dan menggerakkan tungkai dalam renang gaya crawl.

\section{Permainan Bom Nelayan}

Permainan ini dilakukan untuk mengenalkan cara bertahan dengan teknik menghadang bola dalam permainan polo air. Permainan dilakukan dengan cara siswa berkelompok satu banjar kemudian antar siswa saling memegang pungung temannya. Siswa yang ditunjuk untuk memegang bola berusaha melemparkan bola kearah siswa yang berada di barisan belakang dari kelompok yang bergandengan. Tugas dari siswa yang berada diposisi paling depan yaitu berusaha menghadang arah tembakan bola agar tidak mengenai temannya yang dibelakang.

Aspek kognitif yang akan dicapai dalam permainan ini adalah mengenalkan siswa tentang tentang teknik dasar permainan polo air fokusnya yaitu passing bola.

Aspek Afektif yang akan dicapai dalam permainan ini adalah menumbuhkan rasa percaya diri dan bekerjasama antar siswa.

Aspek psikomotor yang akan dicapai meliputi gerak dasar passing bola dalam permainan polo air.

\section{Permainan Lumba Berebut Bola}

Permainan ini dilakukan untuk mengenalkan cara passing antar teman dalam permainan polo air. Permainan dilakukan dengan cara siswa berkelompok membentuk lingkaran. Siswa yang berada di dalam lingkaran berusaha merebut bola. Siswa yang berada di posisi lingkaran yaitu saling mengoper bola antar teman. Saat bola berhasil direbut maka, siswa yang mengoper bola pertama menggantikan siswa yang berada di dalam lingkaran.

Aspek kognitif yang akan dicapai dalam permainan ini adalah mengenalkan siswa tentang tentang teknik dasar permainan polo air fokusnya yaitu passing bola.

Aspek Afektif yang akan dicapai dalam permainan ini adalah menumbuhkan rasa percaya diri dan bekerjasama antar siswa.

Aspek psikomotor yang akan dicapai meliputi gerak dasar passing bola dalam permainan polo air. 


\section{Permainan Lempar Target}

Permainan ini dilakukan untuk mengenalkan cara shooting bola ke arah gawang. Permainan dilakukan dengan cara siswa berkelompok dua banjar saling berseberangan. Setiap siswa membawa bola untuk dilemparkan ke arah sasaran yang ada di depannya.

Aspek kognitif yang akan dicapai dalam permainan ini adalah mengenalkan siswa tentang tentang teknik dasar permainan polo air fokusnya yaitu shooting bola.

Aspek Afektif yang akan dicapai dalam permainan ini adalah menumbuhkan rasa percaya diri dan bekerjasama antar siswa.

Aspek psikomotor yang akan dicapai meliputi gerak dasar shooting bola dalam permainan polo air.

\section{Permainan Lempar Kejar}

Permainan ini dilakukan untuk mengenalkan cara shooting bola ke arah gawang. Permainan dilakukan dengan cara siswa berkelompok satu banjar. Siswa kedua, keempat, keenam memegang bola untuk dilemparkan. Siswa pertama, ketiga, kelima, berusaha mengejar bola dan mengambilnya.

Aspek kognitif yang akan dicapai dalam permainan ini adalah mengenalkan siswa tentang tentang teknik dasar permainan polo air fokusnya yaitu shooting bola, meluncur menggerakkan kedua kaki dan mendayung lengan.

Aspek Afektif yang akan dicapai dalam permainan ini adalah menumbuhkan rasa percaya diri dan bekerjasama antar siswa.

Aspek psikomotor yang akan dicapai meliputi gerak dasar shooting bola, meluncur menggerakkan kedua kaki dan mendayung lengan.

\section{Permainan Polo Air Mini}

Permainan polo air mini merupakan hasil dari modifikasi permainan polo air. Permainan menggunakan ukuran panjang 10 meter dan lebar 5 meter dengan batas lapangan dari tali yang terbuat dari rajutan bola kecil yang berwarna-warni. Ukuran bola lebih kecil dari ukaran bola polo air yang sesungguhnya. Bola terbuat dari karet dan ukuran gawang tinggi gawang 1,5 meter dan panjang 2 meter. Permainan dilakukan dengan bermain polo air mini dengan pemain 5 lawan 5 . Setiap babaknya menggunakan waktu 15 menit.

Aspek kognitif yang akan dicapai dalam permainan ini adalah mengenalkan siswa tentang aturan bermain polo air, jumlah pemain, ukuran gawang, ukuran bola dan luas lapangan.

Aspek Afektif yang akan dicapai dalam permainan ini adalah menumbuhkan rasa percaya diri dan bekerjasama antar siswa.

Aspek psikomotor yang akan dicapai meliputi gerak dasar berlari di air, passing dan shooting bola.

\section{SIMPULAN DAN SARAN}

\section{Simpulan}

Model permainan polo air sebagai pembelajaran pendidikan jasmani bagi siswa sekolah dasar kelas atas merupakan materi aktivitas akuatik yang sesuai dengan kurikulum dan karakteristik siswa sekolah dasar kelas atas. Model permainan polo air sebagai pembelajaran pendidikan jasmani bagi siswa sekolah dasar kelas atas efektif dilaksanakan dalam proses pembelajaran karena dapat mengembangkan nilai-nilai pada aspek kognitif, afektif, dan psikomotor. Kesesuaian model dengan kurikulum ditandai dengan tujuan aspek kognitif, afektif, dan psikomotor berpedoman pada standar kompetensi dan kompetensi dasar siswa sekolah dasar kelas atas.

\section{Saran}

Subjek penelitian sebaiknya dilakukan pada subjek yang lebih luas. Begitu pula dengan tempat penelitian, dilakukan pada lebih banyak tempat penelitian. Diperlukan 
pengembangan model permainan lainnya, misalnya berdasarkan kecabangan untuk siswa kelas atas dalam memenuhi kebutuhan siswa.

\section{DAFTAR PUSTAKA}

Azwar, S. (2004). Penyusunan skala psikologi (Ed 2). Yogyakarta: Pustaka Pelajar.

Dwiyoga, W. G. (2004). Konsep penelitian dan pengembangan. Yogyakarta: UNY Press.

Santoso. (2014). Pembelajaran akuatik prasekolah mengenalkan olahraga air sejak dini. Yogyakarta: UNY Press.

Gall, M.D., Gall, J.P., \& Borg, W.R. (2003). Educational research: an introduction (7th ed). United States of America: Pearson Inc.

Mustafa, Z. (2009). Mengurai variabel hingga instrumentasi. Yogyakarta: Graha Ilmu.

Utami, N., \& Sukadiyanto, S. (2014). MODEL PENGENALAN AIR BAGI SISWA TAMAN KANAK-KANAK. Jurnal Keolahragaan, 2(2), 204-215. Retrieved from http://journal.uny.ac.id/index.php/jolahraga/article/view/2626

Sugiyono. (2015). Metode penelitian \& pengembangan: research and development. Bandung: Alfabeta.

Sun, Haichun (2013). Impact of exergames on physical activity and motivation in elementary school student. Journal of Sport and Health Science 2 (2013), 138-145. 